\title{
Influence of corona discharge on the ozone budget in the tropical free troposphere: a case study of deep convection during GABRIEL
}

\author{
H. Bozem ${ }^{1, *}$, H. Fischer ${ }^{1}$, C. Gurk ${ }^{1}$, C. L. Schiller ${ }^{2}$, U. Parchatka ${ }^{1}$, R. Koenigstedt ${ }^{1}$, A. Stickler ${ }^{1}{ }^{* * *}$, M. Martinez ${ }^{1}$, \\ H. Harder ${ }^{1}$, D. Kubistin ${ }^{1,3}$, J. Williams ${ }^{1}$, G. Eerdekens ${ }^{1, * * *}$, and J. Lelieveld ${ }^{1}$ \\ ${ }^{1}$ Department of Atmospheric Chemistry, Max Planck Institute for Chemistry, Mainz, Germany \\ ${ }^{2}$ Science Division, Environment Canada, Vancouver, Canada \\ ${ }^{3}$ University of Wollongong, School of Chemistry, Wollongong, Australia \\ * now at: Institute for Atmospheric Physics, University Mainz, Mainz, Germany \\ ** now at: Oeschger Centre for Climate Change Research, Bern Switzerland; Institute of Geography, University of Bern, \\ Bern, Switzerland \\ ${ }^{* * *}$ now at: Institute for Reference Materials and Measurements, JRC Geel, Belgium
}

Correspondence to: H. Bozem (bozemh@uni-mainz.de)

Received: 1 December 2013 - Published in Atmos. Chem. Phys. Discuss.: 25 February 2014

Revised: 2 July 2014 - Accepted: 24 July 2014 - Published: 1 September 2014

\begin{abstract}
Convective redistribution of ozone and its precursors between the boundary layer (BL) and the free troposphere (FT) influences photochemistry, in particular in the middle and upper troposphere (UT). We present a case study of convective transport during the GABRIEL campaign over the tropical rain forest in Suriname in October 2005. During one measurement flight the inflow and outflow regions of a cumulonimbus cloud $(\mathrm{Cb})$ have been characterized. We identified a distinct layer between 9 and $11 \mathrm{~km}$ altitude with enhanced mixing ratios of $\mathrm{CO}, \mathrm{O}_{3}, \mathrm{HO}_{\mathrm{x}}$, acetone and acetonitrile. The elevated $\mathrm{O}_{3}$ contradicts the expectation that convective transport brings low-ozone air from the boundary layer to the outflow region. Entrainment of ozone-rich air is estimated to account for $62 \%$ (range: $33-91 \%$ ) of the observed $\mathrm{O}_{3}$. Ozone is enhanced by only $5-6 \%$ by photochemical production in the outflow due to enhanced NO from lightning, based on model calculations using observations including the first reported $\mathrm{HO}_{\mathrm{x}}$ measurements over the tropical rainforest. The "excess" ozone in the outflow is most probably due to direct production by corona discharge associated with lightning. We deduce a production rate of $5.12 \times 10^{28}$ molecules $\mathrm{O}_{3}$ flash $^{-1}$ (range: $9.89 \times 10^{26}$ $9.82 \times 10^{28}$ molecules $\mathrm{O}_{3}$ flash $^{-1}$ ), which is at the upper limit of the range reported previously.
\end{abstract}

\section{Introduction}

Ozone is an important oxidant and known as a primary gaseous component of photochemical smog. High concentrations at ground level are harmful to human health, ecosystems and agriculture whereas the ozone layer in the stratosphere protects life on Earth against hazardous ultraviolet radiation. In the upper troposphere and lower stratosphere region (UTLS) ozone changes can contribute relatively strongly to climate change since ozone is an important greenhouse gas with a radiative forcing of about $0.35 \mathrm{~W} \mathrm{~m}^{-2}$ (IPCC, 2007). Furthermore, ozone is a precursor of the hydroxyl radical $\mathrm{OH}$, which governs the oxidation power of the atmosphere.

In general, the downward transport of ozone from the stratosphere (Holton et al., 1995) and the photochemical production involving volatile organic compounds (VOCs), $\mathrm{CO}$ and NO are sources of tropospheric ozone (Crutzen, 1995; Stevenson et al., 2006). It is well known that electrical corona discharges produce $\mathrm{O}_{3}$. However, experimental evidence from field studies is very sparse. It was first postulated by Shlanta and Moore (1972) that discharges might occur on cloud water droplets or ice particles in highly electrified environments. Griffing (1977) also linked corona discharges to streamer filaments or the surrounding area of lightning channels. Laboratory studies confirm that the production of ozone 
in hot lightning channels is negligible (Wang et al., 1998). In contrast, corona discharge effectively produces ozone, as quantified by Peyrous and Lapeyre (1982) and Simek and Clupek (2002). Hill et al. (1988) estimated the production of $\mathrm{NO}$ and ozone as a function of energy dissipation by corona discharge, yielding a rate of $(1.4 \pm 0.7) \times 10^{16}$ molecules NO per joule and $(4 \pm 2) \times 10^{17}$ molecules $\mathrm{O}_{3}$ per joule, respectively. Minschwaner et al. (2008) suggested a production rate of $1(0.35-1.6) \times 10^{27} \mathrm{O}_{3}$ molecules per flash from balloon measurements in an electrically active thunderstorm in New Mexico, USA. Corona discharge in the vicinity of a lightning flash can be an additional regional source of ozone in convectively active areas. The NO yield from cold discharge (temperature $<3000 \mathrm{~K}$ ) in association with lightning or on cloud droplets is lower compared to hot channel lightning which was already postulated by Donohoe et al. (1977). In the hot flash channel the NO yield maximizes at $4000 \mathrm{~K}$ (Bhetanabhotla et al., 1985; Martinez and Brandvold, 1996; Navarro-González et al., 2001). As shown by many theoretical and experimental studies, hot lightning strokes are a significant global source of $\mathrm{NO}_{\mathrm{x}}$ with a production rate of $15(2-40) \times 10^{25}$ NO molecules per flash (Huntrieser et al., 2007 , and references therein).

The vertical distribution of ozone in the tropical troposphere can typically be described with an S-shaped profile (Thompson et al., 2003). A 1-D model, with the ozone mixing ratio in the convective outflow treated as a free parameter, reproduces this profile reasonably well. In this model vertical advection, including downward transport from the stratosphere, convective transport and photochemical production of ozone are considered (Folkins et al., 2002). This generic ozone profile indicates a local minimum in the remote boundary layer caused by local ozone destruction under warm, moist and low $\mathrm{NO}_{\mathrm{x}}$ conditions (Lelieveld and Crutzen, 1994). This leads to ozone mixing ratios of only a few ppbv in the marine boundary layer (Johnson et al., 1990). In continental regions the $\mathrm{O}_{3}$ mixing ratio typically varies between about 15 and 30 ppbv (Fortuin and Kelder, 1998; Folkins et al., 2002). At higher altitudes there is a local maximum in the profile around $6-7 \mathrm{~km}$ due to reduced ozone destruction compared to the boundary layer. A second local minimum at around $11 \mathrm{~km}$ is caused by convective outflow of ozone poor air, which is transported from the boundary layer to the free troposphere. This influence decreases with increasing altitude leading to increasing ozone above the second local minimum.

In continental areas the local minimum at around $11 \mathrm{~km}$ is not always present (Folkins et al., 2002). In the continental boundary layer ozone precursors from local emissions by vegetation and anthropogenic pollution can have high concentrations. In convective updrafts these precursors are transported into the free troposphere. $\mathrm{NO}_{\mathrm{x}}$ emitted at the surface and lifted to higher altitudes or directly produced from lightning in cumulonimbus clouds (Cbs) contributes to photochemical $\mathrm{O}_{3}$ production. This results in enhanced ozone mix- ing ratios, "filling" up the transport-related local minimum in ozone mixing ratios in the middle or upper troposphere.

During individual events of localized deep convection the atmospheric profile can deviate from the described average "background" situation. Dynamical and chemical mechanisms in association with deep cumulonimbus cloud $(\mathrm{Cb})$ convection can alter the background such that the chemical composition of the middle and upper troposphere downwind is affected for days to weeks after the events. In the case study presented in this work, the influence of deep convection in the tropics on the vertical distribution of ozone is analysed. We observed mean $\mathrm{O}_{3}$ mixing ratios of (24.6 \pm 10.2$)$ ppbv (median: $18.7 \mathrm{ppbv}$ ) in the boundary layer and $(55.2 \pm 2.2)$ ppbv (median: $55.7 \mathrm{ppbv}$ ) in the outflow of an isolated $\mathrm{Cb}$ cloud. This unexpectedly high $\mathrm{O}_{3}$ mixing ratio in the outflow is investigated with respect to the photochemistry and dynamics of a thunderstorm cloud.

Section 2 presents a brief description of the GABRIEL measurement campaign and provides an overview of the instrumentation and the data set obtained for the evaluation of this case study. In Sect. 3, the photochemical ozone production in the convective outflow is estimated. The dynamical transport of air from the lower troposphere into the sampled outflow region and the role of entrainment is investigated in Sect. 4, and Sect. 5 discusses the excess amount of ozone and the potential sources.

\section{GABRIEL 2005}

\subsection{Mission description}

The aircraft measurement campaign GABRIEL 2005 was planned as a follow-up project of LBA-CLAIRE 1998, in Suriname, South America, to investigate the atmospherebiosphere exchange and its impact on atmospheric chemistry in Amazonia. In 2005 an extended state-of-the-art scientific payload was used to quantify $\mathrm{OH}$ and $\mathrm{HO}_{2}$ production and destruction over the tropical rainforest as a function of atmosphere-biosphere interactions and natural VOC emissions during the long dry season (August to November). The role of convective transport on the vertical distribution of primary and secondary gaseous species affecting tropospheric chemistry and trace gas budgets was a further goal of GABRIEL. The measurement platform was a Learjet 35A operated by the Gesellschaft für Flugzieldarstellung (GFD, Hohn, Germany) and based at Johann A. Pengel International Airport at Zanderij $\left(5^{\circ} \mathrm{N}, 55^{\circ} \mathrm{W}\right)$. Table 1 shows an overview of the various measured species and the related measurement techniques that were applied for the different instruments for the GABRIEL campaign. Further information of the measured species is reported in Stickler et al. (2007), Williams et al. (2007), Gebhardt et al. (2008), Eerdekens et al. (2009) and Martinez et al. (2010). 
Table 1. Compendium of the measured species during the GABRIEL campaign.

\begin{tabular}{ll}
\hline Species & Measurement technique \\
\hline $\mathrm{NO}, \mathrm{NO}_{2}, \mathrm{O}_{3}$ & $\begin{array}{l}\text { Chemiluminescence detector (CLD) } \\
\mathrm{JNO}_{2}\end{array}$ \\
$\mathrm{CO}, \mathrm{HCHO}$ & $\begin{array}{l}\text { Filter radiometer } \\
\text { Quantum cascade laser absorption spectrometer } \\
\text { (QCLAS) }\end{array}$ \\
$\mathrm{H}_{2} \mathrm{O}_{2}, \mathrm{ROOH}$ & Dual enzyme fluorescence \\
$\mathrm{OH}, \mathrm{HO}_{2}$ & Laser-induced fluorescence (LIF) \\
$\mathrm{CO}_{2}, \mathrm{H}_{2} \mathrm{O}$ & Non-dispersive infrared absorption detector \\
$\mathrm{VOC}, \mathrm{NMHC}+\mathrm{OVOC}$ & Proton transfer reaction mass spectrometer \\
$($ selected masses) & Gas chromatography and mass spectrometry (canister \\
$\mathrm{NMHC}$ & and cartridge samples) \\
$T, p, \mathrm{RH}$ & Standard techniques \\
Aircraft position & GPS, avionics \\
\hline
\end{tabular}

In 10 measurement flights, of 3 to $3.5 \mathrm{~h}$ each, the troposphere was probed in a region between 3.5 and $6^{\circ} \mathrm{N}$ and between 59 and $51^{\circ} \mathrm{W}$ (Lelieveld et al., 2008). Extensive measurements over the ocean and the pristine tropical rainforest enabled the study of atmosphere-biosphere interactions by contrasting these different environments. The flight patterns were designed to investigate longitudinal and latitudinal trace gas gradients in the boundary layer (BL) and the free troposphere (FT). Identical flight patterns during three different times of the day (morning, noon, afternoon) provide data for the identification of diurnal variations of the measured species.

\subsection{Meteorological conditions}

The location of the Intertropical Convergence Zone (ITCZ) determines to a large extent the weather in Suriname. During the time of the measurement campaign, the ITCZ was localized north of Suriname over the Atlantic and induced southeasterly winds in the lower troposphere caused by the trade wind circulation. The region was further influenced by an upper level trough in the Southern Hemisphere over South America. This induces convergence of air masses in the lower troposphere, whereas in the upper troposphere divergence prevailed. A tropical wave, which propagated westward a few days earlier, was the reason for a very moist lower troposphere. These conditions, and the induced winds, resulted in a potentially unstable troposphere, favourable for the development of single or multicell convection on 12 October, the day of the measurement flight considered here (GAB 08). A few isolated convective cells were observed over Suriname in the late afternoon. One of these single cells was located directly along the flight track. This system was remarkable because of its very rapid development within $3 \mathrm{~h}$.

\subsection{Measurement data}

The flight track and the time series of different species measured on flight GAB 08 on 12 October are shown in Figs. 1 and 2 . The time series data for various trace gas mixing ratios are obtained from a merged data set with a resolution of $30 \mathrm{~s}$. During parts of the flight with no convective influence (17:01-18:42 UTC, 18:55-19:35 UTC), no distinctive features can be identified in the data set, except some peaks at an altitude of around 3 to $4 \mathrm{~km}$ observed for a number of species. These peaks indicate sampling of an air mass affected by biogenic and/or anthropogenic emissions. Enhanced mixing ratios of $\mathrm{CO}, \mathrm{NO}, \mathrm{O}_{3}$ and acetonitrile suggest that biomass burning is at least partly responsible for the pollution.

During the intensive operation period (IOP) of the campaign no major biomass burning events were observed in Suriname or adjacent countries. But plumes of small localized fires could still produce these biomass burning peaks, which had been observed previously over Suriname (Williams et al., 2001). Furthermore, a layer between 3 and $4 \mathrm{~km}$ with enhanced mixing ratios of $\mathrm{CO}$ and $\mathrm{O}_{3}$ was identified on 4 out of 10 measurement flights during the campaign. Above the boundary layer, the so-called trade wind inversion (TWI) leads to an accumulation of emissions from vegetation and local fires (Browell et al., 1988; Jacob and Wofsy, 1988; Krejci et al., 2003, 2005).

Both $\mathrm{O}_{3}$ and $\mathrm{OH}$ have lower mixing ratios in the BL compared to the FT during this flight. In general the BL represents a sink for these species due to reactions with isoprene and other VOCs, which lead to destruction of $\mathrm{O}_{3}$ and $\mathrm{OH}$ at low $\mathrm{NO}_{\mathrm{x}}$ concentrations (Crutzen et al., 1985; Lelieveld et al., 2002; Goldstein et al., 2004; Lelieveld et al., 2008). This is different for other species whose source is at the surface (e.g. CO, acetone, methanol, isoprene), which show high mixing ratios in the $\mathrm{BL}$ and a decrease with altitude. The high mixing ratios result from emissions of these species or 

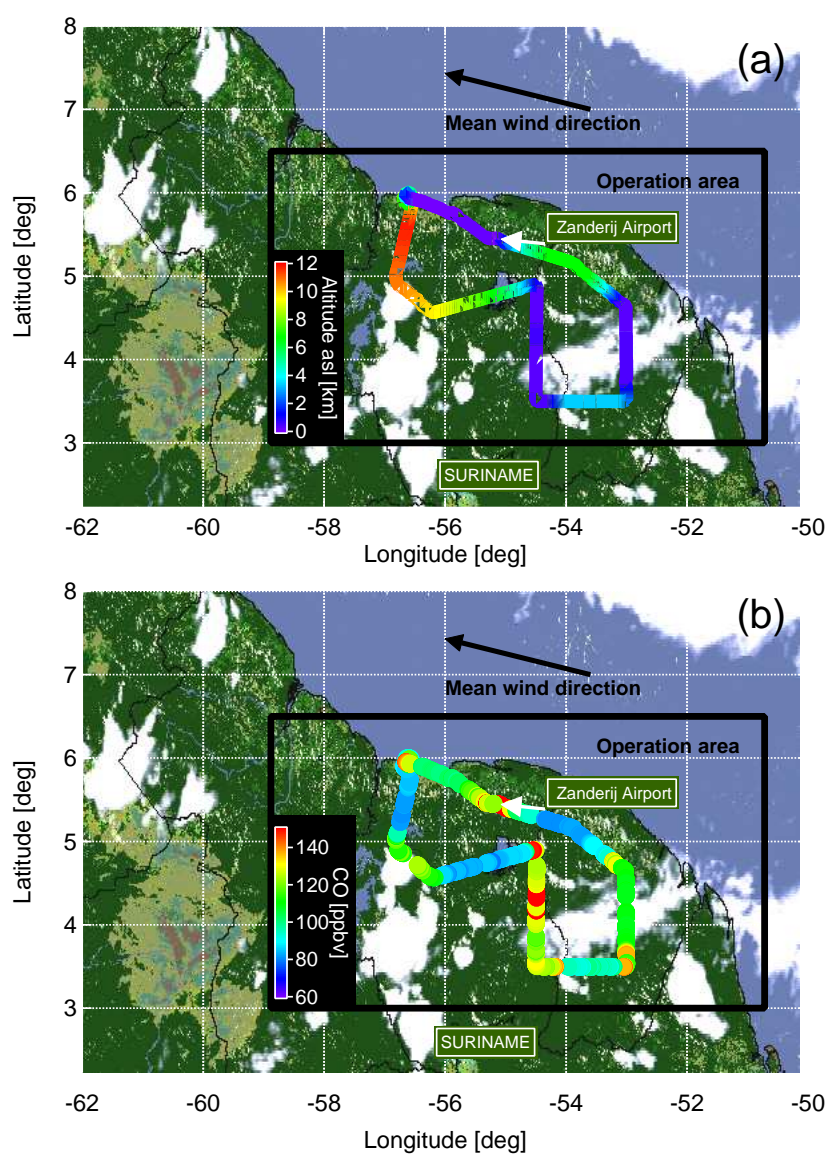

Figure 1. "GOES-12 Regional View" satellite image on 12 October 2005, 19:15 UTC. The operation area of the Learjet 35A during the GABRIEL campaign is indicated with the black rectangle. On the flight track the altitude (a) and the measured CO (b) on flight GAB 08 are colour coded.

their precursors from vegetation and anthropogenic sources followed by the accumulation in the boundary layer during convectively inactive time periods. (Fehsenfeld et al., 1992; Guenther et al., 1995; Kesselmeier and Staudt, 1999).

The convectively influenced part of this flight was between 18:42 UTC and 18:54 UTC during a profile with an ascent to the maximum reachable altitude of $11.6 \mathrm{~km}$ and the subsequent descent back to Zanderij airport. This profile was obtained in the afternoon (local time $=\mathrm{UTC}-3 \mathrm{~h}$ ) when several distinct convective cells had already formed over Suriname. The aircraft approached one of the still developing systems located along the flight track from a southeasterly direction at low altitudes (Fig. 1). The prevailing wind direction on this day in the lower troposphere was also from the southeast, hence part of the flight track transects the inflow region of this cumulonimbus cloud. Flying over this system in a northerly direction, the outflow region was probed. During the ascent almost all species show an enhancement in mixing ratios starting at an altitude of around $9.5 \mathrm{~km}$ (Fig. 3). The mixing ratios stay almost constant (except for some

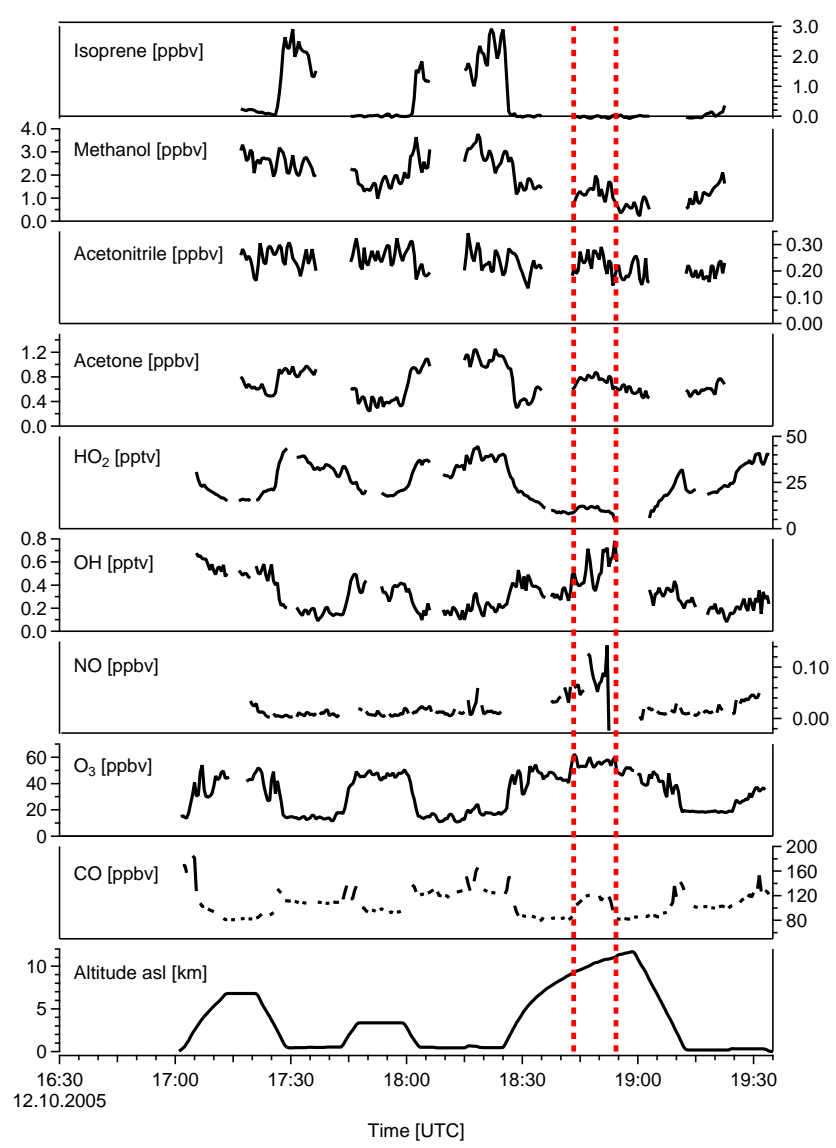

Figure 2. Time series of different species during flight GAB 08. The red dotted lines mark the time interval, where samples were taken in the outflow region of the cumulonimbus cell. The interval spans about $10 \mathrm{~min}$.

small variations) up to $11 \mathrm{~km}$. On a further ascent a strong decrease in the mixing ratios was observed. The enhancement of the different long-lived, and on the timescales of convective transport, chemically inert trace gases compared to background values was between $20.2 \%\left(\mathrm{O}_{3}\right)$ and $38.6 \%$ (CO) (see Table 2). NO was even enhanced by a factor of two. The background values were determined as a mean of all data points sampled during a 5-7 min time interval before and after the convective event respectively. The level of $\mathrm{CO}$ in the outflow $(116.0 \pm 4.3 \mathrm{ppbv})$ was only $12 \%$ less than in the lower troposphere (LT) $(131.7 \pm 10.1 \mathrm{ppbv})$, the layer between 0.4 and $2.8 \mathrm{~km}$ that is capped by the trade wind inversion. Figure 3 shows these comparable mixing ratios for $\mathrm{CO}$, and similar findings are obtained for acetone and acetonitrile, supporting the assumption of convective transport to the upper troposphere with only little dilution. The difference in the mixing ratios in these two altitude regions can therefore be attributed to entrainment of air during the convective uplift of the lower tropospheric air.

A biomass burning plume as a cause of the upper-level trace gas enhancement can be excluded because acetonitrile, 
Table 2. Measured mixing ratios of different species in the outflow of the Cb. For $\mathrm{H}_{2} \mathrm{O}$ an estimation of the mixing ratio from earlier GABRIEL flights was necessary because of an instrument failure during this flight.

\begin{tabular}{lrr|rr|rr}
\hline Species & \multicolumn{7}{|c|}{ Mixing ratio } \\
\hline & $\begin{array}{c}\text { Outflow } \\
\text { Median }\end{array}$ & Mean & \multicolumn{2}{|l|}{ Mackground } & Enhancement [\%] \\
& 55.7 & $55.2 \pm 2.2$ & 46.2 & $46.0 \pm 3.9$ & 20.5 & 20.2 \\
\hline $\mathrm{O}_{3}$ [ppbv] & 117.4 & $116.0 \pm 4.3$ & 83.5 & $83.7 \pm 1.5$ & 40.6 & 38.6 \\
$\mathrm{CO}$ [ppbv] & 0.78 & $0.78 \pm 0.05$ & 0.57 & $0.57 \pm 0.07$ & 37.9 & 37.6 \\
Acetone [ppbv] & 0.24 & $0.25 \pm 0.03$ & 0.18 & $0.20 \pm 0.04$ & 32.5 & 24.7 \\
Acetonitrile [ppbv] & 1.3 & $1.4 \pm 0.3$ & 0.6 & $0.6 \pm 0.2$ & 117.3 & 115.6 \\
Methanol [ppbv] & 75 & $87 \pm 45$ & 32 & $29 \pm 17$ & 131.7 & 197.8 \\
$\mathrm{NO}$ [pptv] & 0.51 & $0.53 \pm 0.13$ & 0.30 & $0.31 \pm 0.04$ & 69.6 & 69.6 \\
$\mathrm{OH}_{\text {[pptv] }}$ & 11.1 & $10.8 \pm 1.3$ & 9.4 & $9.6 \pm 1.1$ & 19.0 & 11.9 \\
$\mathrm{HO}_{2}$ [pptv] & $\mathrm{NA}$ & $270 \pm 20$ & $\mathrm{NA}$ & $270 \pm 20$ & $\mathrm{NA}$ & $\mathrm{NA}$ \\
$\mathrm{H}_{2} \mathrm{O}$ [ppmv] & & & & & & \\
\hline
\end{tabular}

a distinct tracer for biomass burning, is not significantly enhanced (Lobert et al., 1990; Holzinger et al., 1999; Sanhueza et al., 2004).

The mixing ratios of $\mathrm{O}_{3}, \mathrm{NO}, \mathrm{OH}$ and $\mathrm{HO}_{2}$ are remarkably high. The strong enhancement in NO is most probably due to lightning activity. The Lightning Imaging Sensor (LIS) on board the TRMM satellite indicated lightning activity during a flight over the region of interest exactly during the time interval of the measurement flight. As mentioned in the Introduction, lightning flashes (intra-cloud and cloud-toground) play a considerable role as a source of $\mathrm{NO}_{\mathrm{x}}\left(\mathrm{NO}_{\mathrm{x}}\right.$ $=\mathrm{NO}+\mathrm{NO}_{2}$ ) in the upper troposphere (Ridley et al., 1996; Pickering et al., 1998; DeCaria et al., 2000). Especially in the tropics meteorological conditions over land are conducive for convective activity and thunderstorms. Whereas the elevated mixing ratios of the radicals $\mathrm{OH}$ and $\mathrm{HO}_{2}$ can be linked to enhanced photochemical activity and the recycling of these species in a high NO environment in the outflow region of the convective system, the unusual high value of ozone needs to be investigated more deeply. One would expect comparable levels for the mixing ratio in the LT and the outflow, as e.g. observed for $\mathrm{CO}$ and other longer-lived species. In Sects. 3 and 4 we will investigate different processes that potentially enhance ozone, i.e. photochemical ozone production in the outflow during the lifetime of the system and dynamical transport of ozone-rich air from different parts of the troposphere. These processes contribute $35 \mathrm{ppbv}$ to the observed $\mathrm{O}_{3}$ mixing ratio in the outflow region leading to an excess ozone of $20 \mathrm{ppbv}$, which will be investigated in Sect. 5 .

\section{Net photochemical ozone production in the outflow}

Convection plays a crucial role in the vertical transport of different species from the lower to the upper troposphere and is especially important in the Tropics. The tropical rainforest is a significant source region for different species and their emissions are important for the chemistry in the troposphere (Guenther et al., 1995). With respect to ozone production in the outflow of a convective system, emissions of ozone precursors become very important. Volatile organic compounds (VOCs), $\mathrm{CO}$ and nitrogen oxides are emitted into the $\mathrm{BL}$ and transported to the free troposphere by convection within a few hours (Colomb et al., 2006). At these altitudes, the lifetime of VOCs and $\mathrm{NO}_{\mathrm{x}}$ is extended (Dickerson et al., 1987; Barth et al., 2007). The tropical solar radiation further provides the energy for intense photochemistry. Thus in the outflow region, photochemical ozone production can lead to $\mathrm{O}_{3}$ mixing ratios significantly higher than during background conditions (Pickering et al., 1992a).

For this study, the net ozone production rate (NOPR) in the sampled outflow of the cumulonimbus cloud is estimated, thus providing information on the contribution of in situ photochemical ozone production to the measured mixing ratio. To calculate the net ozone production, the relevant reactions for ozone production and ozone destruction are considered. In the troposphere ozone is mainly formed by the reaction of $\mathrm{NO}$ with the hydroperoxy radical $\mathrm{HO}_{2}$ and higher-order peroxyradicals $\mathrm{R}_{\mathrm{i}} \mathrm{O}_{2}$, while photolysis of $\mathrm{O}_{3}$ and subsequent reaction of $\mathrm{O}\left({ }^{1} \mathrm{D}\right)$ with $\mathrm{H}_{2} \mathrm{O}$ as well as reaction of $\mathrm{O}_{3}$ with $\mathrm{OH}$ and $\mathrm{HO}_{2}$ are the major destruction pathways. Further sinks of ozone are the reaction with alkenes, e.g. isoprene and terpenes. The net ozone production rate can be approximated with the following equation (Thompson et al., 1997), if reactions of $\mathrm{O}_{3}$ with alkenes are neglected:

$$
\begin{aligned}
\frac{d}{\mathrm{~d} t}\left[\mathrm{O}_{3}\right] & =k_{1}\left[\mathrm{HO}_{2}\right][\mathrm{NO}]+\sum_{i} k_{i}\left[\mathrm{R}_{i} \mathrm{O}_{2}\right][\mathrm{NO}] \\
& -j_{\mathrm{O}\left({ }^{1} \mathrm{D}\right)}\left[\mathrm{O}_{3}\right]\left[\mathrm{H}_{2} \mathrm{O}\right] m \\
& -k_{2}[\mathrm{OH}]\left[\mathrm{O}_{3}\right] \\
& -k_{3}\left[\mathrm{HO}_{2}\right]\left[\mathrm{O}_{3}\right]
\end{aligned}
$$

where $\mathrm{j}_{\mathrm{O}\left({ }^{1} \mathrm{D}\right)}$ is the photolysis frequency for ozone decomposition from photo dissociation and the $k_{i}$ describe the temperature dependent rate coefficients for the different reactions 


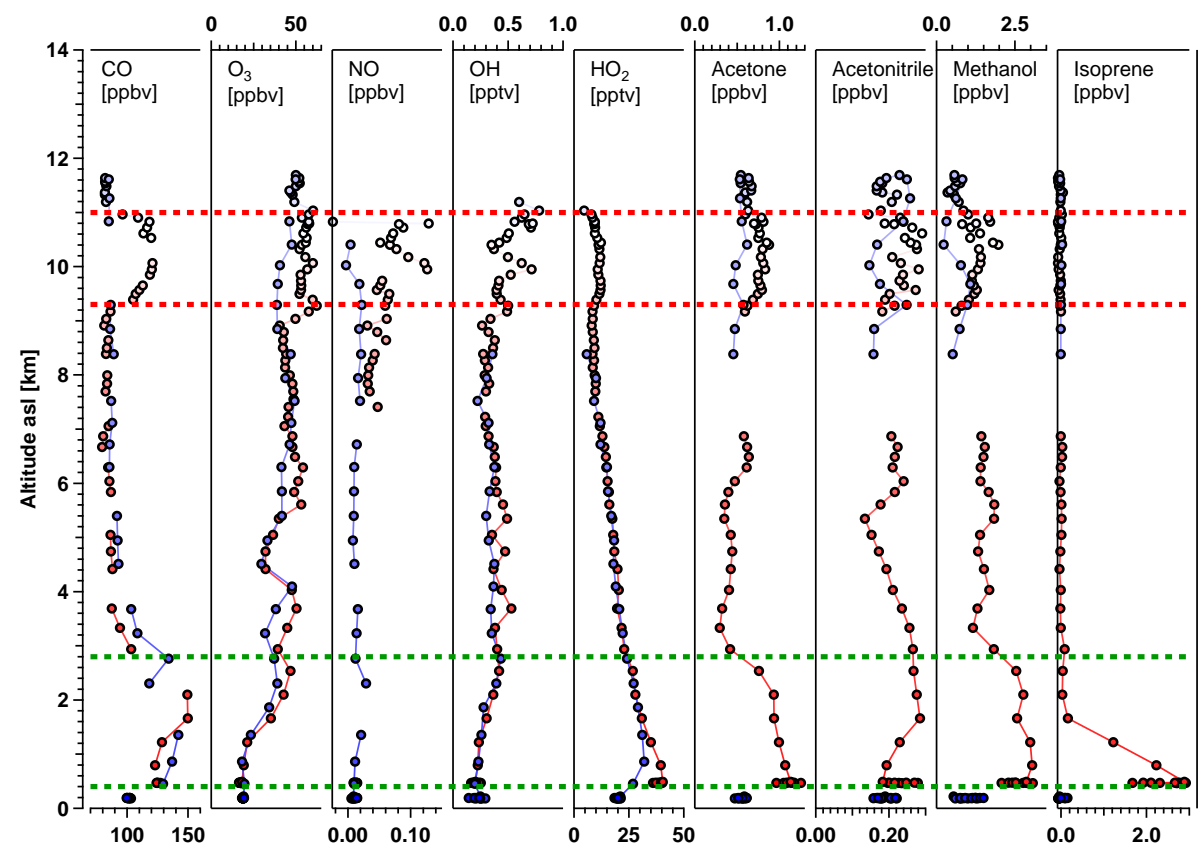

Figure 3. Vertical profiles of different species on measurement flight GAB 08. This plot includes data only from the ascent (reddish coloured data points) and descent (blue coloured data points) at the end of that flight. The red marked height interval characterizes the outflow region, whereas the source region in the lower troposphere for convectively lifted air masses is highlighted in green.

taken from Atkinson et al. (2004). Ozone destruction from photolysis in this equation is a combination of two processes. First, ozone is photolysed forming reactive oxygen $\mathrm{O}\left({ }^{1} \mathrm{D}\right)$, which is converted to atomic oxygen $\mathrm{O}$ by quenching. In this study an explicit description of the quenching with the concentrations of molecular oxygen $\mathrm{O}_{2}$ and molecular nitrogen $\mathrm{N}_{2}$ is used. $\mathrm{O}$ then reacts immediately with $\mathrm{O}_{2}$ to reform ozone. In this so-called null cycle no ozone is destroyed. The prefactor $m$ describes the fraction of $\mathrm{O}\left({ }^{1} \mathrm{D}\right)$ that reacts with $\mathrm{H}_{2} \mathrm{O}$ to form $\mathrm{OH}$ radicals, leading to a destruction of ozone since no reformation of ozone is possible. In the troposphere around $3-10 \%$ of $\mathrm{O}\left({ }^{1} \mathrm{D}\right)$ reacts with $\mathrm{H}_{2} \mathrm{O}$ depending on altitude (Regelin et al., 2013, and references therein).

With the exception of $\mathrm{R}_{\mathrm{i}} \mathrm{O}_{2}$ all relevant species for this estimation were measured. Their mixing ratios in the outflow air are shown in Table 2. The most prominent species of the higher-order peroxy radicals contributing to ozone production is $\mathrm{CH}_{3} \mathrm{O}_{2}$. The contribution of the conversion of $\mathrm{NO}$ to $\mathrm{NO}_{2}$ through $\mathrm{CH}_{3} \mathrm{O}_{2}$ to the net ozone production amounts to $50 \%$ in the boundary layer and could be reduced to $10 \%$ in the upper troposphere, also depending on regional influence (Davis et al., 1996). The mixing ratio of $\mathrm{CH}_{3} \mathrm{O}_{2}$ can be estimated based on the following assumption. Model simulations by Stickler et al. (2007) and Jöckel et al. (2006) showed that the ratio of the production rates of $\mathrm{HO}_{2}$ and $\mathrm{CH}_{3} \mathrm{O}_{2}$ is almost equal to the ratio of their concentrations. We estimated the $\mathrm{CH}_{3} \mathrm{O}_{2}$ mixing ratio from the oxidation of methane using the measured $\mathrm{CH}_{4}$ and $\mathrm{OH}$ mixing ratios.
Based only on measured species a median net ozone production rate of $0.20 \mathrm{ppbv} \mathrm{h}^{-1}$ is estimated. The mean value amounts to $(0.27 \pm 0.13) \mathrm{ppbv} \mathrm{h}^{-1}$ leading to a range of 0.14 to $0.40 \mathrm{ppbv} \mathrm{h}^{-1}$ which accounts for the atmospheric variability of the mixing ratios of these species implemented in the calculation.

To estimate the contribution of photochemical ozone production to the measured $\mathrm{O}_{3}$ mixing ratio in the outflow it is important to consider the life cycle of the convective system, in particular the time interval during which ozone could be produced before the aircraft crossed the outflow. Assuming the maximum estimated ozone production rate of $0.40 \mathrm{ppbvh}^{-1}$ and a time interval of around 3 to $3.5 \mathrm{~h}$ for the active phase of the system, an ozone production of only 1.4 ppbv can be estimated. This is around $2.5 \%$ of the observed value, indicating that ozone production in the outflow has only a small influence on the build-up of ozone during the active phase of this $\mathrm{Cb}$ cloud.

Photochemical net ozone production (NOP) in convective outflow is limited mainly by the amount of available NO (Chameides et al., 1992). In a low- $\mathrm{NO}_{\mathrm{x}}$ environment, up to a few 100 pptv, the NOP increases with increasing $\mathrm{NO}_{\mathrm{x}}$ mixing ratios. The formation of ozone eventually becomes less efficient in a high- $\mathrm{NO}_{\mathrm{x}}$ environment (Liu et al., 1987; Lin et al., 1988). In general, ozone production in convective outflow regions vary over a wide range, from ozone destruction or small net production in remote marine regions (Wang and Prinn, 2000; Mari et al., 2003) to significant net ozone production of several tens of $\mathrm{ppbv} \mathrm{d}^{-1}$ in biomass burning 
plumes transported into the free troposphere (Roelofs et al., 1997; Andreae et al., 2001).

In the literature several studies that address photochemical ozone production in convective outflow in tropical and mid-latitudinal regions can be found. Most studies are based on cloud-scale modelling to estimate the ozone production rates, since in situ measurements of $\mathrm{HO}_{\mathrm{x}}$ and $\mathrm{RO}_{\mathrm{x}}$ are in general missing. To compare our results, being exclusively based on experimental data, with literature data, Table 3 lists results from several case studies in different regions. In Table 3, depending on the availability of the information either a convective enhancement factor (CEF), which describes the ratio of $24 \mathrm{~h}$ post-convective ozone production relative to undisturbed or background conditions, or a net $24 \mathrm{~h}$ ozone production rate is used for comparison.

Since our measurements were performed over tropical South America, in particular a comparison with the studies in this area is interesting, showing that our result falls in the wide range of documented post-convective ozone production in the free troposphere. Our average value tends to be at the lower end of that range.

In our case photochemistry plays only a minor role in the build-up of $\mathrm{O}_{3}$ mixing ratios in the convective outflow. Assuming the upper estimate of the net ozone production rate of $0.40 \mathrm{ppbv} \mathrm{h}^{-1}, 1-2 \mathrm{ppbv} \mathrm{O}_{3}$ is formed during convective activity up to the time of the measurement. DeCaria et al. (2005) calculated an ozone production of around $2 \mathrm{ppbv}$ during the lifetime of a thunderstorm cloud $(\sim 150 \mathrm{~min})$ over North America in the framework of a model simulation of an observed thunderstorm during the STERAO-A mission. The enhanced ozone production in their study is mainly due to high NO mixing ratios caused by lightning activity. Furthermore, a maximum ozone production of $13 \mathrm{ppbv}$ in the first $24 \mathrm{~h}$ downstream of the $\mathrm{Cb}$ cloud was estimated in the STERAO-A study. Assuming no further dilution of the outflow air in our case study, a downstream NOP of nearly $5 \mathrm{ppbv} \mathrm{d}^{-1}$ would be possible. With a net ozone production calculated to be less than $2 \mathrm{ppbv}$ due to photochemistry within the plume, the large enhancement of ozone within the plume cannot be accounted for by photochemistry alone. We will next examine the role of convective transport to the ozone enhancement in the outflow region.

\section{Convective transport of ozone-rich air and the role of entrainment}

Vertical transport in isolated convective cells or organized convection in multiple cells is not restricted to air mass displacement from the boundary layer to the upper troposphere, which is in general one of the main transport pathways (Chatfield and Crutzen, 1984; Pickering et al., 1996; McGee and van den Heever, 2014). During convective transport, air from different layers throughout the whole troposphere can be mixed into the updraft region and lifted to the upper troposphere (UT), a process called entrainment, which can contribute a fraction of more than $50 \%$ to the total mass flux (Dickerson et al., 1987; Fischer et al., 2003). Additionally, detrainment is possible, which means that the outflow of air from the updraft region can be transported outside the cloud into the troposphere below the cloud top (Lawrence and Rasch, 2005).

In the present case the vertical profiles of different lowsolubility tracers such as $\mathrm{CO}$, acetone and acetonitrile (see Fig. 3) clearly indicate vertical transport of air masses from the lower troposphere $(0.4-2.8 \mathrm{~km}$ altitude) to the outflow region in the convective updraft. To characterize the inflow we focus on the region in the lower troposphere between $0.4-2.8 \mathrm{~km}$ altitude, and the data points in the lower BL (below $0.4 \mathrm{~km}$ ) were excluded, since they were collected over coastal areas and are thus not representative for the tropical rainforest. The $\mathrm{BL}$ is capped by an inversion layer at $3.0 \mathrm{~km}$, which was observed on several flights during the campaign. This so-called trade wind inversion has been reported in different studies on tropical regions and is known to act as an effective transport barrier so that trace species can accumulate in the BL (Schubert et al., 1995; Gouget et al., 1996; Andreae et al., 2001). The vertical profile of CO shows a high mixing ratio of $(131.7 \pm 10.1)$ ppbv in the lower troposphere and a slightly lower value of $(116.0 \pm 4.3) \mathrm{ppbv}$ in the outflow region. The difference in the observed mixing ratios might be due to entrainment of air during vertical transport or mixing with background air in the outflow region. In general observed $\mathrm{O}_{3}$ mixing ratios in the troposphere below the convective outflow are not high enough to balance the more than 20 ppbv unaccounted ozone in the outflow. Highest $\mathrm{O}_{3}$ values in the background air close to the outflow region and the structure of the vertical profile of CO support the assumption that lower tropospheric air is diluted in the upper troposphere after convective upward transport in the thunderstorm cloud.

By means of a budget of the different insoluble long-lived trace gases, the fraction of air from the different layers contributing to the outflow mixing ratio can be investigated. Following Fischer et al. (2003) the mixing ratio of an inert trace gas in the outflow of the $\mathrm{Cb}$ cloud can be described with the following equation:

$$
X^{\mathrm{Out}}=a \cdot X^{\mathrm{LT}}+(1-a) \cdot X^{\mathrm{Entr}} .
$$

With this equation an ideal situation is investigated, i.e. when mixing involves only two layers. $X^{\text {Out }}$ describes the mixing ratio in the convective outflow and $X^{\mathrm{LT}}$ the corresponding mixing ratio in the lower troposphere (LT). The mixing ratio in the second layer, the entrainment layer, is denoted by $X^{\text {Entr }}$. The parameter $a$ stands for the fraction of air that enters the updraft region of the $\mathrm{Cb}$ from the lower troposphere. It is calculated from Eq. (2):

$$
a=\frac{X^{\text {Out }}-X^{\text {Entr }}}{X^{\mathrm{LT}}-X^{\text {Entr }}}
$$


Table 3. Convective ozone production enhancement (adopted and modified from Pickering et al., 1992a).

\begin{tabular}{|c|c|c|c|}
\hline Study & Description & $\begin{array}{l}\text { Mid and upper troposphere } \\
\text { outflow CEF }\end{array}$ & $\begin{array}{l}\text { OPR } \\
{\left[p_{\left.p b v d^{-1}\right]}\right.}\end{array}$ \\
\hline \multicolumn{4}{|c|}{ Tropical regions } \\
\hline 1 & $\begin{array}{l}\text { ABLE 2A, } 3 \text { Aug 1985; } \\
\text { Pickering et al. (1991) }\end{array}$ & OPR: $-\rightarrow+$ & 0.2 \\
\hline 2 & $\begin{array}{l}\text { ABLE 2A storm, savanna burning; } \\
\text { Pickering et al. (1992b) }\end{array}$ & 53 & 7.4 \\
\hline 3 & $\begin{array}{l}\text { ABLE 2A storm, forest burning; } \\
\text { Pickering et al. (1992b) }\end{array}$ & 59 & 8.5 \\
\hline 4 & $\begin{array}{l}\text { ABLE 2B, } 6 \text { May 1987; } \\
\text { Scala et al. (1990) }\end{array}$ & $\sim 1$ & \\
\hline 5 & $\begin{array}{l}\text { STEP/EMEX, } 2 \text { Feb 1987; } \\
\text { Pickering et al. (1993) }\end{array}$ & $<1$ & $<1$ \\
\hline \multirow[t]{3}{*}{6} & $\begin{array}{l}\text { ABLE 2B, } 26 \text { Apr 1987; } \\
\text { Pickering et al. (1992a) }\end{array}$ & & \\
\hline & Rural air & 2.5 & $1.5-1.7$ \\
\hline & Urban air & 35 & $16.5-17.2$ \\
\hline 7 & $\begin{array}{l}\text { Indonesia, BIBLE-A, Oct 1998; } \\
\text { Kita et al. (2003) }\end{array}$ & & 1.8 \\
\hline 8 & $\begin{array}{l}\text { South Atlantic, TRACE-A, 26-27 Sep 1992; } \\
\text { Thompson et al. (1997) }\end{array}$ & $3-3.5$ & \\
\hline 9 & $\begin{array}{l}\text { Pacific, PEM-Tropics, Oct 1992; } \\
\text { Schultz et al. (1999) }\end{array}$ & & $1-1.5$ \\
\hline 10 & $\begin{array}{l}\text { Western Pacific, BIBLE-C, Dec 2000; } \\
\text { Koike et al. (2007) }\end{array}$ & $3.7 / 2.9$ & $1.95 / 1.52$ \\
\hline 11 & $\begin{array}{l}\text { South America, TROCCINOX } 2004 \text { and 2005; } \\
\text { Huntrieser et al. (2007) }\end{array}$ & indication for strong ozone $\mathrm{p}$ & roduction \\
\hline \multirow[t]{2}{*}{12} & This study; median (range) & & \\
\hline & GABRIEL, 12 Oct 2005 & 3.6 & $2.40(1.68-4.80)$ \\
\hline \multicolumn{4}{|c|}{ Mid-latitudinal regions } \\
\hline 13 & $\begin{array}{l}\text { Oklahoma, PRESTORM, } 15 \text { Jun 1985; } \\
\text { Pickering et al. (1990) }\end{array}$ & 4 & $\sim 15$ \\
\hline \multirow[t]{3}{*}{14} & $\begin{array}{l}\text { Oklahoma, PRESTORM, } 10 \text { Jun 1985; } \\
\text { Pickering et al. (1992a) }\end{array}$ & & \\
\hline & Rural air & 2.5 & $5.7-6.2$ \\
\hline & Urban air & 3.9 & $9.4-9.9$ \\
\hline 15 & $\begin{array}{l}\text { North America, STERAO-A, } 12 \text { Jul 1996; } \\
\text { DeCaria et al. (2005) }\end{array}$ & & $10-13$ \\
\hline 16 & $\begin{array}{l}\text { Central Europe, EULINOX, } 21 \text { Jul } 1998 \\
\text { Ott et al. (2007) }\end{array}$ & & $\begin{array}{l}1.5 \text { (cloud outflow) } \\
\max : 5 \text { (at } 5.5 \mathrm{~km} \text { a.s.1.) }\end{array}$ \\
\hline 17 & $\begin{array}{l}\text { HOOVER II, } 17 \text { Jul 2007; median (range) } \\
\text { Bozem (2010) }\end{array}$ & 6.5 & $22.68(19.44-26.16)$ \\
\hline
\end{tabular}

The corresponding factor $(1-a)$ gives the fraction of entrainment into the updraft or outflow region. Values for $a$ were calculated from the data points in the outflow, where trace gas mixing ratios exceed background values by $3 \sigma$ standard deviations.

For the calculation of the fraction $a$ the assumption is made that air in the outflow consists of lower tropospheric air (0.4-2.8 km altitude) and entrained air from outside the cloud at the same altitude as the outflow (Fig. 3). From the observed mean mixing ratios in Table 4 using $\mathrm{CO}$ and acetone, the fraction $a$ of $(56 \pm 29) \%$ of outflow air originating in the lower troposphere was calculated. Correspondingly, $(44 \pm 29) \%$ of outflow air was entrained from the upper troposphere. Using these numbers to calculate the outflow mixing ratio of ozone we obtain with Eq. (2) a value of $(34.0 \pm 16.0)$ ppbv. That is $(62 \pm 29) \%$ of the observed 
Table 4. Average mixing ratios and associated standard deviation of different trace gases in the considered layers.

\begin{tabular}{lcccc}
\hline Layer & $\begin{array}{c}\mathrm{CO} \\
{[\mathrm{ppbv}]}\end{array}$ & $\begin{array}{c}\text { Acetone } \\
{[\mathrm{ppbv}]}\end{array}$ & $\begin{array}{c}\text { Acetonitrile } \\
{[\mathrm{ppbv}]}\end{array}$ & $\begin{array}{c}\text { Ozone } \\
{[\mathrm{ppbv}]}\end{array}$ \\
\hline Lower troposphere $(0.4-2.8 \mathrm{~km})$ & $131.7 \pm 10.1$ & $1.05 \pm 0.13$ & $0.24 \pm 0.04$ & $24.6 \pm 10.2$ \\
Entrainment & $83.7 \pm 1.5$ & $0.57 \pm 0.07$ & $0.20 \pm 0.04$ & $46.0 \pm 3.9$ \\
Outflow & $116.0 \pm 4.3$ & $0.78 \pm 0.05$ & $0.25 \pm 0.03$ & $55.2 \pm 2.2$ \\
\hline
\end{tabular}

mixing ratio. The range given for each parameter represents the atmospheric variability of the different species especially in the lower troposphere which is due to the different emission regimes within the tropical rain forest (see Fig. 1) that were probed. The measurement uncertainty of the different instruments is much smaller compared to the variability of these species in the measurement regimes. To account for the variability, we additionally calculate the range of the different parameters. Thus the estimated $\mathrm{O}_{3}$ mixing ratio is between 18.0 and $50.0 \mathrm{ppbv}$, which then could explain between 33 and $91 \%$ of the observed outflow value.

Taking together the mean contributions from photochemical ozone production in the convective outflow and dynamical transport including entrainment, $(65 \pm 29) \%$ of the observed $\mathrm{O}_{3}$ value in the convective outflow could be explained, hence there are $(35 \pm 29) \%$ of ozone unaccounted for in the budget. There are different mechanisms and processes including a more complex chemistry, complex mixing or transport processes or entrainment of ozone-rich air as well as ozone production directly from electrical discharges that can contribute to the excess ozone. The different processes are considered in the next section.

\section{Missing ozone source}

A more complex chemistry can be excluded as an additional ozone source in the convective outflow. As shown in Sect. 3, photochemical ozone production tends to be too slow to significantly contribute to the observed outflow value. Also heterogeneous chemistry inside the thunderstorm cloud is not known to produce significant amounts of ozone.

Potentially more important is the enhancement of $\mathrm{O}_{3}$ in the upper troposphere due to complex mixing or transport processes that were not considered. As mentioned in Sect. 4, entrainment can play an important role within a convective system. Dickerson et al. (1987) and Fischer et al. (2003) showed that during strong convection events not exclusively air masses from the boundary layer are lifted to the upper troposphere or even into the stratosphere. Entrainment from various layers in the troposphere influences the trace gas mixing ratios in the convective outflow. However, as shown in Fig. 3 there are no regions in the vertical $\mathrm{O}_{3}$ profile that can lead to a significant enhancement of the outflow mixing ratio due to entrainment of ozone-rich air during upward transport.

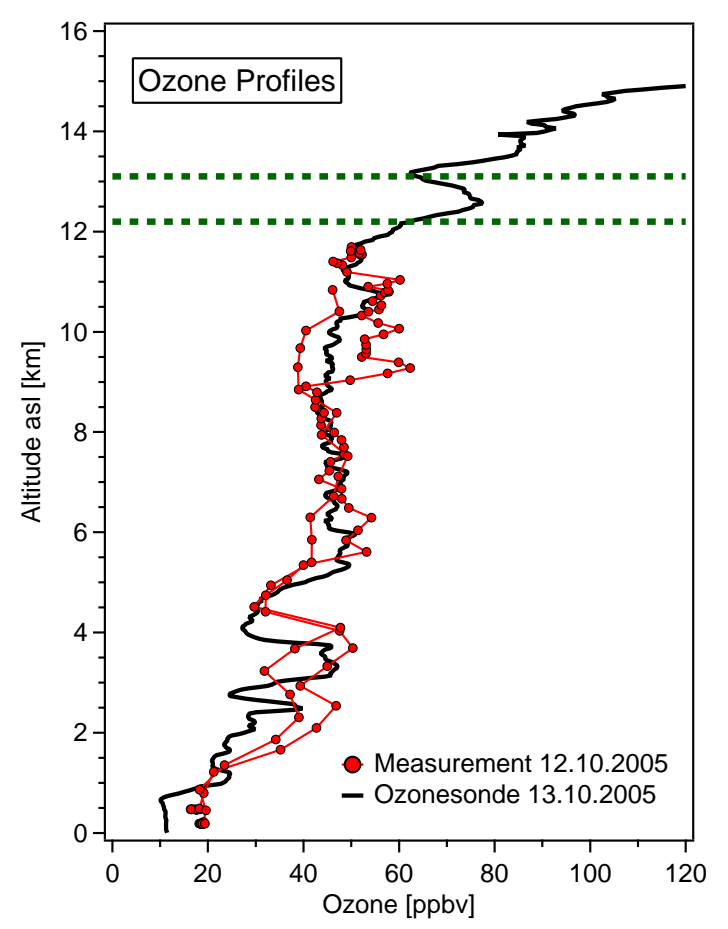

Figure 4. Ozone radio sounding data from the SHADOZ network station in Paramaribo, Suriname. The plot shows vertical profiles including sounding data from 13 October 2005 (black line) and Learjet 35A measurement data from 12 October 2005. The green dotted lines mark the height interval with enhanced $\mathrm{O}_{3}$ mixing ratios.

Several previous studies discussed downward vertical transport in association with deep convection. In our case, downward transport from the stratosphere into the anvil region as observed by Wang et al. (1995), Poulida et al. (1996), Stenchikov et al. (1996) and Dye et al. (2000) can be excluded because the tropopause was situated more than $3 \mathrm{~km}$ above the cloud top, as derived from temperature and ozone profiles from radio soundings in Paramaribo (see Fig. 4). Scala et al. (1990) and Salzmann et al. (2004) suggested rear inflow in mesoscale convective systems taking place in association with downward transport in the troposphere. This mechanism and cloud top entrainment (Boatman and Auer, 1983; Blyth et al., 1988) seem to be potential processes that could mix ozone-rich air in the anvil region from the layer above. 


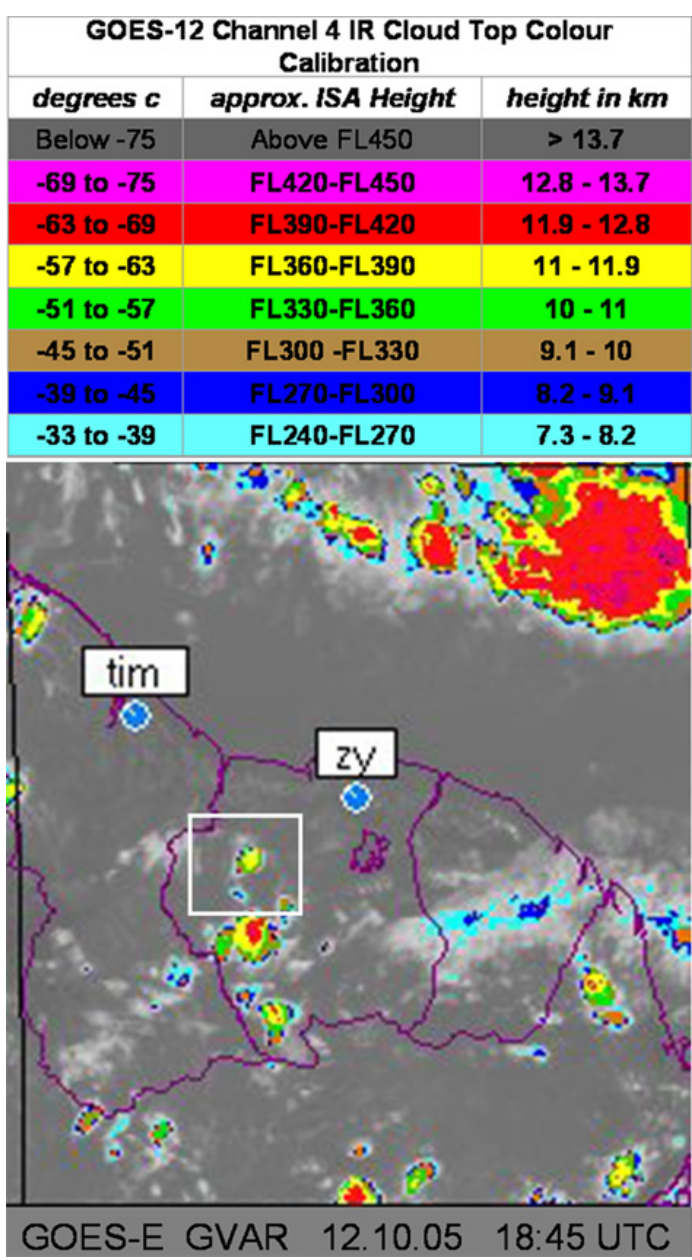

Figure 5. GOES-12 infrared channel satellite image of the GABRIEL observation area from 12 October, 18:45 UTC. The cloud top height is colour coded as described in the table above the image. The white square marks the investigated isolated thunderstorm cloud.

As can be seen in Fig. 5, another isolated thunderstorm with a cloud top height of $\sim 13 \mathrm{~km}$ was located around $100 \mathrm{~km}$ south of the investigated $\mathrm{Cb}$ for this case study. The dynamics of this more intensive convective system may have affected the trace gas mixing ratios in the outflow of the $\mathrm{Cb}$ under investigation. The southern $\mathrm{Cb}$ cloud top reached up to a layer with ozone-rich air and larger scale subsidence in the vicinity of its updraft core may lead to a downward transport and subsequent mixing of ozone-rich air into the outflow region of the system within the white square.

A strong argument against this additional ozone source is the mixing ratio of the longer-lived species as for example $\mathrm{CO}$. The mixing ratio of $\mathrm{CO}$ is expected to decrease with increasing altitude leading to a decrease of the outflow mixing ratios in cases of strong entrainment of upper tropospheric ozone-rich air. But since there are no measurements in that altitude region, we do not have further information on $\mathrm{CO}$ and other trace gas mixing ratios in the upper troposphere, which makes this mechanism still possible, although unlikely.

Detrainment was not included in this idealized argument. The transport of air from the updraft core into the environment in different layers below the outflow region is not expected to influence the trace gas mixing ratios in the outflow (Lawrence and Rasch, 2005). Nevertheless, detrainment can influence the chemical composition of the free troposphere below the outflow region (Pickering et al., 1992a; Ott et al., 2007).

Another yet poorly quantified mechanism is ozone production directly from electrical discharges associated with lightning. Laboratory studies indicate possible ozone formation from corona discharges (Levine et al., 1981; Peyrous and Lapeyre, 1982; Simek and Clupek, 2002). Ozone formation in inlet lines or on the fuselage of aircrafts has been documented to lead to measurement artefacts (Ridley et al., 2006, and references therein) whereas experimental evidence for ozone production by electrical discharges in the free troposphere is inconclusive. Shlanta and Moore (1972), Winterrath et al. (1999) and Zahn et al. (2002) suggested direct ozone production from corona discharge to explain the observed enhanced mixing ratios in a thunderstorm cloud and convectively active areas, respectively. In these studies no yield of $\mathrm{O}_{3}$ molecules per flash is given. A study by Hill et al. (1988) states a range of $0.2-2.0 \times 10^{27}$ molecules $\mathrm{O}_{3}$ per flash whereas Minschwaner et al. (2008) showed a significant amount of ozone formed by corona discharge in a thunderstorm cloud with an estimated value of 0.35 $1.6 \times 10^{27}$ molecules $\mathrm{O}_{3}$ per flash.

In this study we considered different processes to explain the missing ozone source. None of these processes can close the gap between the observed $\mathrm{O}_{3}$ mixing ratio in the outflow and the contribution from photochemical production and convective transport. Hence based on the assumption that the excess ozone of $(19.8 \pm 16.0)$ ppbv is produced from corona discharge in the vicinity of lightning flashes we estimate a production rate of molecules $\mathrm{O}_{3}$ per flash. If we further assume that the enhanced NO mixing ratios in the convective outflow also result from lightning, we can compare the ratio of the known values of excess $\mathrm{O}_{3}$ and enhanced $\mathrm{NO}$ with the ratio of $\mathrm{O}_{3}$ per flash and $\mathrm{NO}$ per flash:

$$
\frac{\mathrm{O}_{3} \text { [excess] }}{\mathrm{NO} \text { [enhancement] }}=\frac{\mathrm{O}_{3} \text { flash }^{-1}}{\mathrm{NOflash}^{-1}} \text {. }
$$

With the rate of $1.5 \times 10^{26}$ molecules NO flash ${ }^{-1}$ being the best estimate proposed by Schumann and Huntrieser (2007) and with Eq. (4), a rate of $5.12 \times 10^{28}$ molecules $_{3}$ flash $^{-1}$ (median: $8.80 \times 10^{28}$ molecules $\mathrm{O}_{3}$ flash $^{-1}$ ) is estimated. Including the atmospheric variability affecting the excess ozone mentioned in Sect. 4, a range of $4.18 \times 10^{27}$ $9.82 \times 10^{28}$ molecules $\mathrm{O}_{3}$ flash $^{-1}$ is calculated. The lower limit of that range is based on the maximum contribution 
of dynamical processes (50.0 ppbv) and photochemical production (1.4 ppbv) to the observed outflow mixing ratio leading to only $6.9 \%$ of unaccounted ozone. Compared to known values in the literature, our corresponding lower limit of the value for the rate of $\mathrm{O}_{3} \mathrm{flash}^{-1}$ is of the same order of magnitude but nevertheless a factor of 5 higher compared to the values proposed by Minschwaner et al. (2008). Following the maximum contribution of dynamical processes and using the maximum observed NO value of $231 \mathrm{pptv}$ in the convective outflow, the contribution of photochemical ozone production enhances to $3.1 \mathrm{ppbv}$ and the lower limit for the range of lightning $\mathrm{O}_{3}$ decreases to $9.89 \times 10^{26}$ molecules $\mathrm{O}_{3}$ flash $^{-1}$.

\section{Conclusions}

Based on in situ observations from the airborne field measurement campaign GABRIEL in 2005, including the first $\mathrm{HO}_{\mathrm{x}}$ measurements over the tropical rainforest, we investigated trace gas budgets in the convective outflow of a mature thunderstorm cloud. The ozone budget was analysed in detail by differentiating between photochemical net ozone production and dynamical processes to explain the strong enhancement of ozone mixing ratios in the outflow. The analysis shows that predominantly dynamical, rather than photochemical processes determine the trace gas mixing ratios in the outflow region during the first hours of a developing $\mathrm{Cb}$ cloud. The fraction of $91 \%$ for the maximum contribution of convective transport of air from the lower troposphere and entrainment of ozone-rich air into the outflow region in the upper troposphere, respectively, exceeds the maximum fraction of $5.6 \%$ from net photochemical ozone production (based on 231 pptv NO) by at least a factor of 16 . The contribution of photochemical net ozone production increases when the evolution of the mixing ratio downstream of the system is considered during the first $24 \mathrm{~h}$ after the development. Assuming no further entrainment into the outflow, approximately $5-11 \mathrm{ppbv}$ of $\mathrm{O}_{3}$ can be produced within $24 \mathrm{~h}$ depending on the abundance of NO.

Even by considering the upper part of the uncertainty range of the estimated dynamical transport and photochemical ozone production their integral cannot close the ozone budget in the outflow. Different processes to explain the excess ozone have been considered. Whereas an additional photochemical source of ozone can be precluded on the short timescales of $\mathrm{Cb}$ development, unknown mixing and transport processes could not be fully excluded, although they seem rather unlikely. Consequently, ozone formation in corona discharges appears to be the most probable source of $\mathrm{O}_{3}$. This case study therefore corroborates that ozone from corona discharge associated with lightning strikes is not negligible and is perhaps a larger source than previously assumed. To better quantify the range of the rate of $\mathrm{O}_{3}$ per flash and to estimate the global influence of this ozone source ad- ditional measurements in electrified thunderstorm clouds are necessary.

Acknowledgements. The authors are very grateful to the GABRIEL team, enviscope GmbH and GFD for their excellent support. Their work was essential for a successful realization of the measurement campaign. We are also grateful for the good cooperation with the Suriname Meteorological Service (MDS) and the Anton de Kom University of Suriname (both Paramaribo, Suriname).

The service charges for this open access publication have been covered by the Max Planck Society.

Edited by: R. Cohen

\section{References}

Andreae, M., Artaxo, P., Fischer, H., Freitas, S., Gregoire, J., Hansel, A., Hoor, P., Kormann, R., Krejci, R., Lange, L., Lelieveld, J., Lindinger, W., Longo, K., Peters, W., de Reus, M., Scheeren, B., Dias, M., Strom, J., van Velthoven, P., and Williams, J.: Transport of biomass burning smoke to the upper troposphere by deep convection in the equatorial region, Geophys. Res. Lett., 28, 951-954, doi:10.1029/2000GL012391, 2001.

Atkinson, R., Baulch, D. L., Cox, R. A., Crowley, J. N., Hampson, R. F., Hynes, R. G., Jenkin, M. E., Rossi, M. J., and Troe, J.: Evaluated kinetic and photochemical data for atmospheric chemistry: Volume $\mathrm{I}-$ gas phase reactions of $\mathrm{O}_{\mathrm{x}}, \mathrm{HO}_{\mathrm{x}}, \mathrm{NO}_{\mathrm{x}}$ and $\mathrm{SO}_{\mathrm{x}}$ species, Atmos. Chem. Phys., 4, 1461-1738, doi:10.5194/acp-41461-2004, 2004.

Barth, M. C., Kim, S. W., Skamarock, W. C., Stuart, A. L., Pickering, K. E., and Ott, L. E.: Simulations of the redistribution of formaldehyde, formic acid, and peroxides in the 10 July 1996 stratospheric-tropospheric experiment: radiation, aerosols, and ozone deep convection storm, J. Geophys. Res.-Atmos., 112, 124, doi:10.1029/2006jd008046, 2007.

Bhetanabhotla, M. N., Crowell, B. A., Coucouvinos, A., Hill, R. D., and Rinker, R. G.: Simulation of Trace Species Production By Lightning and Corona Discharge in Moist Air, Atmos. Environ., 19, 1391-1397, doi:10.1016/0004-6981(85)90276-8, 1985.

Blyth, A. M., Cooper, W. A., and Jensen, J. B.: A Study of the Source of Entrained Air in Montana Cumuli, J. Atmos. Sci., 45, 3944-3964, 1988.

Boatman, J. F. and Auer, A. H.: The Role of Cloud Top Entrainment in Cumulus Clouds, J. Atmos. Sci., 40, 1517-1534, 1983.

Bozem, H.: Photochemie der Troposphäre in niedrigen und mittleren Breiten: Die Rolle von Konvektion, Ph.D. thesis, International Max Planck Research School for Atmospheric Chemistry and Physics, 2010.

Browell, E. V., Gregory, G. L., Harriss, R. C., and Kirchhoff, V. W. J. H.: Tropospheric Ozone and Aerosol Distributions Across the Amazon Basin, J. Geophys. Res.-Atmos., 93, 1431-1451, doi:10.1029/JD093iD02p01431, 1988.

Chameides, W. L., Fehsenfeld, F., Rodgers, M. O., Cardelino, C., Martinez, J., Parrish, D., Lonneman, W., Lawson, D. R., Rasmussen, R. A., Zimmerman, P., Greenberg, J., Middleton, P., and 
Wang, T.: Ozone Precursor Relationships in the Ambient Atmosphere, J. Geophys. Res.-Atmos., 97, 6037-6055, 1992.

Chatfield, R. B. and Crutzen, P. J.: Sulfur-Dioxide in Remote Oceanic Air - Cloud Transport of Reactive Precursors, J. Geophys. Res.-Atmos., 89, 7111-7132, 1984.

Colomb, A., Williams, J., Crowley, J., Gros, V., Hofmann, R., Salisbury, G., Klupfel, T., Kormann, R., Stickler, A., Forster, C., and Lelieveld, J.: Airborne measurements of trace organic species in the upper troposphere over Europe: the impact of deep convection, Environ. Chem., 3, 244-259, doi:10.1071/EN06020, 2006.

Crutzen, P. J.: Overview of tropospheric chemistry: Developments during the past quarter century and a look ahead, in: Faraday Disussions on Atmospheric Chemistry - Measurements, Mechanics and Models, vol. 100, 1-21, Royal Soc. Chemistry, Cambridge, 1995.

Crutzen, P. J., Delany, A. C., Greenberg, J., Haagenson, P., Heidt, L., Lueb, R., Pollock, W., Seiler, W., Wartburg, A., and Zimmerman, P.: Tropospheric Chemical Composition Measurements in Brazil During the Dry Season, J. Atmos. Chem., 2, 233-256, 1985.

Davis, D. D., Crawford, J., Chen, G., Chameides, W., Liu, S., Bradshaw, J., Sandholm, S., Sachse, G., Gregory, G., Anderson, B., Barrick, J., Bachmeier, A., Collins, J., Browell, E., Blake, D., Rowland, S., Kondo, Y., Singh, H., Talbot, R., Heikes, B., Merrill, J., Rodriguez, J., and Newell, R. E.: Assessment of ozone photochemistry in the western North Pacific as inferred from PEM-West A observations during the fall 1991, J. Geophys. Res.Atmos., 101, 2111-2134, doi:10.1029/95JD02755, 1996.

DeCaria, A. J., Pickering, K. E., Stenchikov, G. L., Scala, J. R., Stith, J. L., Dye, J. E., Ridley, B. A., and Laroche, P.: A cloudscale model study of lightning-generated $\mathrm{NO}_{\mathrm{x}}$ in an individual thunderstorm during STERAO-A, J. Geophys. Res.-Atmos., 105, 11601-11616, doi:10.1029/2000JD900033, 2000.

DeCaria, A. J., Pickering, K. E., Stenchikov, G. L., and Ott, L. E.: Lightning-generated $\mathrm{NO}_{\mathrm{x}}$ and its impact on tropospheric ozone production: A three-dimensional modeling study of a Stratosphere-Troposphere Experiment: Radiation, Aerosols and Ozone (STERAO-A) thunderstorm, J. Geophys. Res.-Atmos., 110, D14303, doi:10.1029/2004jd005556, 2005.

Dickerson, R. R., Huffman, G. J., Luke, W. T., Nunnermacker, L. J., Pickering, K. E., Leslie, A. C. D., Lindsey, C. G., Slinn, W. G. N., Kelly, T. J., Daum, P. H., Delany, A. C., Greenberg, J. P., Zimmerman, P. R., Boatman, J. F., Ray, J. D., and Stedman, D. H.: Thunderstorms - An Important Mechanism in the Transport ot Air Pollutants, Science, 235, 460-464, 1987.

Donohoe, K. G., Shair, F. H., and Wulf, O.: Production of $\mathrm{O}_{3}$, NO, and $\mathrm{N}_{2} \mathrm{O}$ in a Pulsed Discharge at 1 Atm, Ind. Eng. Chem. Fund., 16, 208-215, doi:10.1021/i160062a006, 1977.

Dye, J. E., Ridley, B. A., Skamarock, W., Barth, M., Venticinque, M., Defer, E., Blanchet, P., Thery, C., Laroche, P., Baumann, K., Hubler, G., Parrish, D. D., Ryerson, T., Trainer, M., Frost, G., Holloway, J. S., Matejka, T., Bartels, D., Fehsenfeld, F. C., Tuck, A., Rutledge, S. A., Lang, T., Stith, J., and Zerr, R.: An overview of the Stratospheric-Tropospheric Experiment: Radiation, Aerosols, and Ozone (STERAO)-Deep Convection experiment with results for the July 10, 1996 storm, J. Geophys. Res.Atmos., 105, 10023-10045, doi:10.1029/1999JD901116, 2000.

Eerdekens, G., Ganzeveld, L., Vilà-Guerau de Arellano, J., Klüpfel, T., Sinha, V., Yassaa, N., Williams, J., Harder, H., Kubistin, D., Martinez, M., and Lelieveld, J.: Flux estimates of isoprene, methanol and acetone from airborne PTR-MS measurements over the tropical rainforest during the GABRIEL 2005 campaign, Atmos. Chem. Phys., 9, 4207-4227, doi:10.5194/acp-9-42072009, 2009.

Fehsenfeld, F., Calvert, J., Fall, R., Goldan, P., Guenther, A. B., Hewitt, C. N., Lamb, B., Liu, S., and Trainer, M.: Emissions of volatile organic compounds from vegetation and the implications for atmospheric chemistry, Global Biogeochem. Cy., 6, 389-430, 1992.

Fischer, H., de Reus, M., Traub, M., Williams, J., Lelieveld, J., de Gouw, J., Warneke, C., Schlager, H., Minikin, A., Scheele, R., and Siegmund, P.: Deep convective injection of boundary layer air into the lowermost stratosphere at midlatitudes, Atmos. Chem. Phys., 3, 739-745, doi:10.5194/acp-3-739-2003, 2003.

Folkins, I., Braun, C., Thompson, A. M., and Witte, J.: Tropical ozone as an indicator of deep convection, J. Geophys. Res.-Atmos, 107, ACH13-1-ACH13-10, doi:10.1029/2001JD001178, 2002.

Fortuin, J. and Kelder, H.: An ozone climatology based on ozonesonde and satellite measurements, J. Geophys. Res.Atmos., 103, 31709-31734, 1998.

Gebhardt, S., Colomb, A., Hofmann, R., Williams, J., and Lelieveld, J.: Halogenated organic species over the tropical South American rainforest, Atmos. Chem. Phys., 8, 3185-3197, doi:10.5194/acp8-3185-2008, 2008

Goldstein, A. H., McKay, M., Kurpius, M. R., Schade, G. W., Lee, A., Holzinger, R., and Rasmussen, R. A.: Forest thinning experiment confirms ozone deposition to forest canopy is dominated by reaction with biogenic VOCs, Geophys. Res. Lett., 31, L22106, doi:10.1029/2004g1021259, 2004.

Gouget, H., Cammas, J. P., Marenco, A., Rosset, R., and Jonquieres, I.: Ozone peaks associated with a subtropical tropopause fold and with the trade wind inversion: A case study from the airborne campaign TROPOZ II over the Caribbean in winter, J. Geophys. Res.-Atmos., 101, 25979-25993, doi:10.1029/96JD01545, 1996.

Griffing, G. W.: Ozone and Oxides of Nitrogen Production During Thunderstorms, J. Geophys. Res.-Atmos., 82, 943-950, doi:10.1029/JC082i006p00943, 1977.

Guenther, A., Hewitt, C. N., Erickson, D., Fall, R., Geron, C., Graedel, T., Harley, P., Klinger, L., Lerdau, M., McKay, W. A., Pierce, T., Scholes, B., Steinbrecher, R., Tallamraju, R., Taylor, J., and Zimmerman, P.: A global model of natural volatile organic compound emissions, J. Geophys. Res.-Atmos., 100, 8873-8892, doi:10.1029/94JD02950, 1995.

Hill, R., Rahmin, I., and Rinker, R.: Experimental Study of the Production of $\mathrm{NO}, \mathrm{N}_{2} \mathrm{O}$, and $\mathrm{O}_{3}$ in a Simulated Atmospheric Corona, Ind. Eng. Chem. Res., 27, 1264-1269, doi:10.1021/ie00079a029, 1988.

Holton, J. R., Haynes, P. H., McIntyre, M. E., Douglass, A. R., Rood, R. B., and Pfister, L.: Stratosphere-Troposphere Exchange, Rev. Geophys., 33, 403-439, 1995.

Holzinger, R., Warneke, C., Hansel, A., Jordan, A., Lindinger, W., Scharffe, D. H., Schade, G., and Crutzen, P. J.: Biomass burning as a source of formaldehyde, acetaldehyde, methanol, acetone, acetonitrile, and hydrogen cyanide, Geophys. Res. Lett., 26, 1161-1164, doi:10.1029/1999GL900156, 1999.

Huntrieser, H., Schlager, H., Roiger, A., Lichtenstern, M., Schumann, U., Kurz, C., Brunner, D., Schwierz, C., Richter, A., and Stohl, A.: Lightning-produced $\mathrm{NO}_{\mathrm{x}}$ over Brazil during TROC- 
CINOX: airborne measurements in tropical and subtropical thunderstorms and the importance of mesoscale convective systems, Atmos. Chem. Phys., 7, 2987-3013, doi:10.5194/acp-7-29872007, 2007.

IPCC: Climate Change 2007 - The Physical Science Basis: Contribution of Working Group I to the Fourth Assessment Report of the Intergovernmental Panel on Climate Change, in: Climate Change 2007, edited by: Solomon, S., Qin, D., Manning, M., Chen, Z., Marquis, M., Averyt, K. B., Tignor, M., and Miller, H. L., Cambridge University Press, Cambridge, United Kingdom and New York, NY, USA, 2007.

Jacob, D. J. and Wofsy, S. C.: Photochemistry of Biogenic Emissions Over the Amazon Forest, J. Geophys. Res.-Atmos., 93, 1477-1486, doi:10.1029/JD093iD02p01477, 1988.

Jöckel, P., Tost, H., Pozzer, A., Brühl, C., Buchholz, J., Ganzeveld, L., Hoor, P., Kerkweg, A., Lawrence, M. G., Sander, R., Steil, B., Stiller, G., Tanarhte, M., Taraborrelli, D., van Aardenne, J., and Lelieveld, J.: The atmospheric chemistry general circulation model ECHAM5/MESSy1: consistent simulation of ozone from the surface to the mesosphere, Atmos. Chem. Phys., 6, 50675104, doi:10.5194/acp-6-5067-2006, 2006.

Johnson, J. E., Gammon, R. H., Larsen, J., Bates, T. S., Oltmans, S. J., and Farmer, J. C.: Ozone in the Marine Boundary Layer Over the Pacific and Indian Oceans: Latitudinal Gradients and Diurnal Cycles, J. Geophys. Res.-Atmos., 95, 11847-11856, doi:10.1029/JD095iD08p11847, 1990.

Kesselmeier, J. and Staudt, M.: Biogenic volatile organic compounds (VOC): An overview on emission, physiology and ecology, J. Atmos. Chem., 33, 23-88, 1999.

Kita, K., Kawakami, S., Miyazaki, Y., Higashi, Y., Kondo, Y., Nishi, N., Koike, M., Blake, D. R., Machida, T., Sano, T., Hu, W., Ko, M., and Ogawa, T.: Photochemical production of ozone in the upper troposphere in association with cumulus convection over Indonesia, J. Geophys. Res., 108, BIB4-1-BIB4-19, doi:10.1029/2001jd000844, 2003.

Koike, M., Kondo, Y., Kita, K., Takegawa, N., Nishi, N., Kashihara, T., Kawakami, S., Kudoh, S., Blake, D., Shirai, T., Liley, B., Ko, M., Miyazaki, Y., Kawasaki, Z., and Ogawa, T.: Measurements of reactive nitrogen produced by tropical thunderstorms during BIBLE-C, J. Geophys. Res.-Atmos., 112, D18304, doi:10.1029/2006jd008193, 2007.

Krejci, R., Strom, J., de Reus, M., Hoor, P., Williams, J., Fischer, H., and Hansson, H. C.: Evolution of aerosol properties over the rain forest in Surinam, South America, observed from aircraft during the LBA-CLAIRE 98 experiment, J. Geophys. Res.-Atmos., 108, AAC1-1-AAC1-17, doi:10.1029/2001jd001375, 2003.

Krejci, R., Ström, J., de Reus, M., and Sahle, W.: Single particle analysis of the accumulation mode aerosol over the northeast Amazonian tropical rain forest, Surinam, South America, Atmos. Chem. Phys., 5, 3331-3344, doi:10.5194/acp-5-3331-2005, 2005.

Lawrence, M. G. and Rasch, P. J.: Tracer transport in deep convective updrafts: Plume ensemble versus bulk formulations, J. Atmos. Sci., 62, 2880-2894, 2005.

Lelieveld, J. and Crutzen, P. J.: Role of Deep Cloud Convection in the Ozone Budget of the Troposphere, Science, 264, 1759-1761, 1994.
Lelieveld, J., Peters, W., Dentener, F. J., and Krol, M. C.: Stability of tropospheric hydroxyl chemistry, J. Geophys. Res.-Atmos., 107, ACH17-1-ACH17-11, doi:10.1029/2002jd002272, 2002.

Lelieveld, J., Butler, T. M., Crowley, J. N., Dillon, T. J., Fischer, H., Ganzeveld, L., Harder, H., Lawrence, M. G., Martinez, M., Taraborrelli, D., and Williams, J.: Atmospheric oxidation capacity sustained by a tropical forest, Nature, 452, 737-740, 2008.

Levine, J. S., Rogowski, R. S., Gregory, G. L., Howell, W. E., and Fishman, J.: Simultaneous Measurements of $\mathrm{NO}_{\mathrm{x}}$, NO, and O3 Production in a Laboratory Discharge - Atmospheric Implications, Geophys. Res. Lett., 8, 357-360, doi:10.1029/GL008i004p00357, 1981.

Lin, X., Trainer, M., and Liu, S. C.: On the nonlinearity of the Tropospheric Ozone Production, J. Geophys. Res.-Atmos., 93, 15879-15888, doi:10.1029/JD093iD12p15879, 1988.

Liu, S. C., Trainer, M., Fehsenfeld, F. C., Parrish, D. D., Williams, E. J., Fahey, D. W., Hubler, G., and Murphy, P. C.: Ozone Production in the Rural Troposphere and the Implications for Regional and Global Ozone Distributions, J. Geophys. Res.-Atmos., 92, 4191-4207, doi:10.1029/JD092iD04p04191, 1987.

Lobert, J. M., Scharffe, D. H., Hao, W. M., and Crutzen, P. J.: Importance of Biomass Burning in the Atmospheric Budgets of Nitrogen-Containing Gases, Nature, 346, 552-554, doi:10.1038/346552a0, 1990.

Mari, C., Saut, C., Jacob, D. J., Staudt, A., Avery, M. A., Brune, W. H., Faloona, I., Heikes, B. G., Sachse, G. W., Sandholm, S. T., Singh, H. B., and Tans, D.: On the relative role of convection, chemistry, and transport over the South Pacific Convergence Zone during PEM-Tropics B: A case study, J. Geophys. Res.Atmos., 108, PEM4-1-PEM4-16, doi:10.1029/2001jd001466, 2003.

Martinez, M., Harder, H., Kubistin, D., Rudolf, M., Bozem, H., Eerdekens, G., Fischer, H., Klüpfel, T., Gurk, C., Königstedt, R., Parchatka, U., Schiller, C. L., Stickler, A., Williams, J., and Lelieveld, J.: Hydroxyl radicals in the tropical troposphere over the Suriname rainforest: airborne measurements, Atmos. Chem. Phys., 10, 3759-3773, doi:10.5194/acp-10-3759-2010, 2010.

Martinez, P. and Brandvold, D. K.: Laboratory and field measurements of $\mathrm{NO}_{\mathrm{x}}$ produced from corona discharge, Atmos. Environ. 30, 4177-4182, doi:10.1016/1352-2310(96)00156-2, 1996.

McGee, C. J. and van den Heever, S. C.: Latent Heating and Mixing due to Entrainment in Tropical Deep Convection, J. Atmos. Sci., 71, 816-832, doi:10.1175/JAS-D-13-0140.1, 2014.

Minschwaner, K., Kalnajs, L. E., Dubey, M. K., Avallone, L. M., Sawaengphokai, P. C., Edens, H. E., and Winn, W. P.: Observation of enhanced ozone in an electrically active storm over Socorro, NM: Implications for ozone production from corona discharges, J. Geophys. Res.-Atmos., 113, D17208, doi:10.1029/2007jd009500, 2008.

Navarro-González, R., Villagran-Muniz, M., Sobral, H., Molina, L. T., and Molina, M. J.: The physical mechanism of nitric oxide formation in simulated lightning, Geophys. Res. Lett., 28, 3867 3870, doi:10.1029/2001GL013170, 2001.

Ott, L. E., Pickering, K. E., Stenchikov, G. L., Huntrieser, H., and Schumann, U.: Effects of lightning $\mathrm{NO}_{\mathrm{x}}$ production during the 21 July European lightning nitrogen oxides project storm studied with a three-dimensional cloud-scale chemical transport model, J. Geophys. Res.-Atmos., 112, D05307, doi:10.1029/2006jd007365, 2007. 
Peyrous, R. and Lapeyre, R. M.: Gaseous Products Created by Electrical Discharges in the Atmosphere and Condensation Nuclei Resulting from Gaseous-Phase Reactions, Atmos. Environ., 16, 959-968, 1982.

Pickering, K. E., Thompson, A. M., Dickerson, R. R., Luke, W. T., McNamara, D. P., Greenberg, J. P., and Zimmerman, P. R.: Model Calculations of Tropospheric Ozone Production Potential Following Observed Convective Events, J. Geophys. Res.-Atmos., 95, 14049-14062, doi:10.1029/JD095iD09p14049, 1990.

Pickering, K. E., Thompson, A. M., Scala, J. R., Tao, W. K., Simpson, J., and Garstang, M.: Photochemical Ozone Production in Tropical Squall Line Convection During NASA Global Tropospheric Experiment Amazon Boundary Layer Experiment 2A, J. Geophys. Res.-Atmos., 96, 3099-3114, 1991.

Pickering, K. E., Thompson, A. M., Scala, J. R., Tao, W. K., Dickerson, R. R., and Simpson, J.: Free Tropospheric Ozone Production Following Entrainment of Urban Plumes Into Deep Convection, J. Geophys. Res.-Atmos., 97, 17985-18000, 1992a.

Pickering, K. E., Thompson, A. M., Scala, J. R., Tao, W. K., and Simpson, J.: Ozone Production Potential Following Convective Redistribution of Biomass Burning Emissions, J. Atmos. Chem., 14, 297-313, 1992b.

Pickering, K. E., Thompson, A. M., Tao, W. K., and Kucsera, T. L.: Upper Tropospheric Ozone Production Following Mesoscale Convection During STEP/EMEX, J. Geophys. Res.-Atmos., 98, 8737-8749, doi:10.1029/93JD00875, 1993.

Pickering, K. E., Thompson, A. M., Wang, Y. S., Tao, W. K., McNamara, D. P., Kirchhoff, V. W. J. H., Heikes, B. G., Sachse, G. W., Bradshaw, J. D., Gregory, G. L., and Blake, D. R.: Convective transport of biomass burning emissions over Brazil during TRACE A, J. Geophys. Res.-Atmos., 101, 23993-24012, 1996.

Pickering, K. E., Wang, Y. S., Tao, W. K., Price, C., and Muller, J. F.: Vertical distributions of lightning NO for use in regional and global chemical transport models, J. Geophys. Res.-Atmos., 103, 31203-31216, doi:10.1029/98JD02651, 1998.

Poulida, O., Dickerson, R. R., and Heymsfield, A.: Stratospheretroposphere exchange in a midlatitude mesoscale convective complex, 1. Observations, J. Geophys. Res.-Atmos., 101, 68236836, doi:10.1029/95JD03523, 1996.

Regelin, E., Harder, H., Martinez, M., Kubistin, D., Tatum Ernest, C., Bozem, H., Klippel, T., Hosaynali-Beygi, Z., Fischer, H., Sander, R., Jöckel, P., Königstedt, R., and Lelieveld, J.: $\mathrm{HO}_{\mathrm{x}}$ measurements in the summertime upper troposphere over Europe: a comparison of observations to a box model and a 3-D model, Atmos. Chem. Phys., 13, 10703-10720, doi:10.5194/acp13-10703-2013, 2013.

Ridley, B. A., Dye, J. E., Walega, J. G., Zheng, J., Grahek, F. E., and Rison, W.: On the production of active nitrogen by thunderstorms over New Mexico, J. Geophys. Res.-Atmos., 101, 20985-21005, doi:10.1029/96JD01706, 1996

Ridley, B. A., Avery, M. A., Plant, J. V., Vay, S. A., Montzka, D. D., Weinheimer, A. J., Knapp, D. J., Dye, J. E., and Richard, E. C.: Sampling of Chemical Constituents in Electrically Active Convective Systems: Results and Cautions, J. Atmos. Chem., 54, 120, doi:10.1007/s10874-005-9007-5, 2006.

Roelofs, G. J., Lelieveld, J., Smit, H. G. J., and Kley, D.: Ozone production and transports in the tropical Atlantic region during the biomass burning season, J. Geophys. Res.-Atmos., 102, 1063710651, doi:10.1029/97JD00400, 1997.
Salzmann, M., Lawrence, M. G., Phillips, V. T. J., and Donner, L. J.: Modelling tracer transport by a cumulus ensemble: lateral boundary conditions and large-scale ascent, Atmos. Chem. Phys., 4, 1797-1811, doi:10.5194/acp-4-1797-2004, 2004.

Sanhueza, E., Holzinger, R., Kleiss, B., Donoso, L., and Crutzen, P. J.: New insights in the global cycle of acetonitrile: release from theocean and dry deposition in the tropical savanna of Venezuela, Atmos. Chem. Phys., 4, 275-280, doi:10.5194/acp-4-275-2004, 2004.

Scala, J. R., Garstang, M., Tao, W. K., Pickering, K. E., Thompson, A. M., Simpson, J., Kirchhoff, V., Browell, E. V., Sachse, G. W., Torres, A. L., Gregory, G. L., Rasmussen, R. A., and Khalil, M. A. K.: Cloud Draft Structure and Trace Gas Transport, J. Geophys. Res.-Atmos., 95, 17015-17030, doi:10.1029/JD095iD10p17015, 1990.

Schubert, W. H., Ciesielski, P. E., Lu, C. G., and Johnson, R. H.: Dynamical Adjustment of the Trade-Wind Inversion Layer, J. Atmos. Sci., 52, 2941-2952, doi:10.1175/15200469(1995)052<2941:DAOTTW>2.0.CO;2, 1995.

Schultz, M. G., Jacob, D. J., Wang, Y. H., Logan, J. A., Atlas, E. L., Blake, D. R., Blake, N. J., Bradshaw, J. D., Browell, E. V., Fenn, M. A., Flocke, F., Gregory, G. L., Heikes, B. G., Sachse, G. W., Sandholm, S. T., Shetter, R. E., Singh, H. B., and Talbot, R. W.: On the origin of tropospheric ozone and $\mathrm{NO}_{\mathrm{x}}$ over the tropical South Pacific, J. Geophys. Res.-Atmos., 104, 5829-5843, 1999.

Schumann, U. and Huntrieser, H.: The global lightning-induced nitrogen oxides source, Atmos. Chem. Phys., 7, 3823-3907, doi:10.5194/acp-7-3823-2007, 2007.

Shlanta, A. and Moore, C. B.: Ozone and Point Discharge Measurements under Thunderclouds, J. Geophys. Res., 77, 4500-4510, doi:10.1029/JC077i024p04500, 1972.

Simek, M. and Clupek, M.: Efficiency of ozone production by pulsed positive corona discharge in synthetic air, J. Phys. D Appl. Phys., 35, 1171-1175, 2002.

Stenchikov, G., Dickerson, R., Pickering, K., Ellis, W., Doddridge, B., Kondragunta, S., Poulida, O., Scala, J., and Tao, W. K.: Stratosphere-troposphere exchange in a midlatitude mesoscale convective complex, 2. Numerical simulations, J. Geophys. Res.Atmos., 101, 6837-6851, doi:10.1029/95JD02468, 1996.

Stevenson, D., Dentener, F., Schultz, M., Ellingsen, K., van Noije, T., Wild, O., Zeng, G., Amann, M., Atherton, C., Bell, N., Bergmann, D., Bey, I., Butler, T., Cofala, J., Collins, W., Derwent, R., Doherty, R., Drevet, J., Eskes, H., Fiore, A., Gauss, M., Hauglustaine, D., Horowitz, L., Isaksen, I., Krol, M., Lamarque, J., Lawrence, M., Montanaro, V., Muller, J., Pitari, G., Prather, M., Pyle, J., Rast, S., Rodriguez, J., Sanderson, M., Savage, N., Shindell, D., Strahan, S., Sudo, K., and Szopa, S.: Multimodel ensemble simulations of present-day and near-future tropospheric ozone, J. Geophys. Res.-Atmos., 111, D08301, doi:10.1029/2005JD006338, 2006.

Stickler, A., Fischer, H., Bozem, H., Gurk, C., Schiller, C., Martinez-Harder, M., Kubistin, D., Harder, H., Williams, J., Eerdekens, G., Yassaa, N., Ganzeveld, L., Sander, R., and Lelieveld, J.: Chemistry, transport and dry deposition of trace gases in the boundary layer over the tropical Atlantic Ocean and the Guyanas during the GABRIEL field campaign, Atmos. Chem. Phys., 7, 3933-3956, doi:10.5194/acp-7-3933-2007, 2007. 
Thompson, A. M., Tao, W. K., Pickering, K. E., Scala, J. R., and Simpson, J.: Tropical Deep Convection and Ozone Formation, B. Am. Meteorol. Soc., 78, 1043-1054, 1997.

Thompson, A. M., Witte, J. C., Oltmans, S. J., Schmidlin, F. J., Logan, J. A., Fujiwara, M., Kirchhoff, V. W. J. H., Posny, F., Coetzee, G. J. R., Hoegger, B., Kawakami, S., Ogawa, T., Fortuin, J. P. F., and Kelder, H. M.: Southern Hemisphere Additional Ozonesondes (SHADOZ) 1998-2000 tropical ozone climatology. 2. Tropospheric variability and the zonal wave-one, J. Geophys. Res.-Atmos., 108, PEM13-1-PEM1321, doi:10.1029/2002jd002241, 2003.

Wang, C. and Prinn, R. G.: On the roles of deep convective clouds in tropospheric chemistry, J. Geophys. Res.-Atmos., 105, 22269 22297, doi:10.1029/2000JD900263, 2000.

Wang, C., Crutzen, P. J., Ramanathan, V., and Williams, S. F.: The role of a deep convective storm over the tropical Pacific Ocean in the redistribution of atmospheric chemical species, J. Geophys. Res.-Atmos., 100, 11509-11516, doi:10.1029/95JD01173, 1995.

Wang, Y., DeSilva, A. W., Goldenbaum, G. C., and Dickerson, R. R.: Nitric oxide production by simulated lightning: Dependence on current, energy, and pressure, J. Geophys. Res.-Atmos., 103, 19149-19159, doi:10.1029/98JD01356, 1998.
Williams, J., Fischer, H., Hoor, P., Poeschl, U., Crutzen, P., Andreae, M., and Lelieveld, J.: The influence of the tropical rainforest on atmospheric $\mathrm{CO}$ and $\mathrm{CO}_{2}$ as measured by aircraft over Surinam, South America, Chemosphere Global Change Sci, 3, 157-170, 2001.

Williams, J., Yassaa, N., Bartenbach, S., and Lelieveld, J.: Mirror image hydrocarbons from Tropical and Boreal forests, Atmos. Chem. Phys., 7, 973-980, doi:10.5194/acp-7-973-2007, 2007.

Winterrath, T., Kurosu, T. P., Richter, A., and Burrows, J. P.: Enhanced $\mathrm{O}_{3}$ and $\mathrm{NO}_{2}$ in thunderstorm clouds: Convection or production?, Geophys. Res. Lett., 26, 1291-1294, doi:10.1029/1999GL900243, 1999.

Zahn, A., Brenninkmeijer, C. A. M., Crutzen, P. J., Parrish, D. D., Sueper, D., Heinrich, G., Gusten, H., Fischer, H., Hermann, M., and Heintzenberg, J.: Electrical discharge source for tropospheric "ozone-rich transients", J. Geophys. Res.-Atmos., 107, 4638, doi:10.1029/2002JD002345, 2002. 